\title{
Some Observations on Group Work with Adult Stammerers
}

\author{
by \\ R. FAWCUS L.C.S.T. \\ M. A. FAWCUS L.C.S.T.
}

\section{Organisation of the Groups.}

The London County Council has for many years held evening classes for adult stammerers. Until 1956, general relaxation was a fundamental part of treatment. The present approach dates from this period, when one of us was appointed as a speech therapist and "non-avoidance" techniques were introduced. The classes are now affiliated to the City Literary Institute, which holds a wide variety of classes in the arts and the humanities.

Students from the age of 16 years enrol in the evening groups for adult stammerers with no more formality than the completion of a short form, and the payment of a fee of 25 shillings. This fee entitles them to attend twice weekly over the entire academic year (a period of nine months from October to June). There are now three therapists, each taking two groups a week, and groups are now available four nights a week. Those stammerers who come twice weekly (approximately $50 \%$ of the total this year) seldom see the same therapist on both evenings. We feel that this policy not only helps to sustain their interest, but helps them to gain a broader view of the problem. Facilities for individual discussion are always made available when necessary, particularly on a Thursday evening, when two therapists are present both before and after the regular class session. More often than not on this evening, one or two students stay on for an informal discussion after the class, or else come in early for a talk. We find very few stammerers requiring regular individual help.

Little or no attempt is made to "screen" stammerers who want to join the classes, and the main factor determining which group or groups the student joins will be the particular evening on which he wants to come. This results in a fairly random selection, with a present age range of 16 to 55 years. In addition to this wide age range, there are varied racial, social and educational backgrounds.
This year we have students from Ceylon, Ghana, India, Ireland, Libya, Nigeria, South Africa and the West Indies. Nonetheless, the common problem of stammering makes this a homogenous group in the psychotherapeutic sense. A total of 50 students have enrolled since the end of September: 28 of the total enrolment are new students, and the remainder are in their second or third year.

These are "open groups" in the sense used by Anthony (1957) since students are enrolling at intervals throughout the year. It is advocated that the homogenous group should be run on closed lines, but not only would this be impossible in practice, but we believe there is a positive value in exposing the stammerers to the stress both of new mem. bers and visitors (such as speech therapy students) joining the group. Whilst our attendance varies from 7-13 students, our experience confirms Anthony's statement that 8 is the "ideal" number for a therapeutic group.

Origins and Rationale of our Approach.

Working with groups of stammerers over a period of 6 years has led to a growing conviction that the stammerer is basically a normal speaker, with normal and understandable speech fears, sometimes resulting in withdrawal, sometimes in aggression, but all within the range of normal human behaviour. Dean Williams, considering research findings on stammering comments: "According to present day knowledge, it appears most reasonable to conclude that those persons who come to be classified by themselves or by others as stutterers are not distinctive from other persons, either neuro-physiologically or either in respect to basic personality structure". From our experience, the really neurotic stammerer stands out in a group by his persistent resistance to treatment, by his failure to become an integrated part of the group, or by other abnormal patterns of social behaviour. Evidence seems to suggest that the incidence of neurosis 
amongst stammerers is much the same as that among the population as a whole.

The question of whether stammering is or is not a symptom of neurosis is, of course, a perennially controversial one. One tends, naturally, to interpret evidence according to what one believes, but we are increasingly impressed by the essentially normal behaviour of stammerers. We have therefore based our approach to the problem on the assumption that the stammerer is a "normal" person with a normal speech mechanism, and that the stammering can be considered as a functionally autonomous disorder of communication. Qualitatively and quantitatively he has the same kind of emotional problems as the normal speaker, plus those anxieties arising secondary to the stammer. It is in fact, a functional speech disorder in the purest sense.

Physical symptoms, such as biochemic, cardiac and respiratory changes which have been noted in the extensive literature on the subject are again held to be the effect rather than the cause of stammering, since none of these seem to be incompatible with either the symptoms of fear experienced by a normal speaker or with what one can see and hear the stammerer doing when he stammers. To illustrate our point with an example: there are still therapists, particularly in Europe, who set out to re-educate the stammerer's breathing pattern on the basis of their findings of abnormal pneumographic recordings. During so-called "normal" or fluent speech, we have found only one or two stammerers who showed a sufficiently abnormal breathing pattern to interfere with speech in any way. Yet during stammering the majority of stammerers will exhibit an abnormal pattern for any one or more of the following reasons:

(a) Because he wants to say as much as he can on a single breath (to avoid the "difficulties" of stopping and starting again), so that he continues speaking on residual air.

(b) Because he makes an "anticipatory inspiration", an habitual reaction to a feared word which probably has its roots in the mistaken advice to take a deep breath by a well-meaning parent, teacher or friend, or because he feels he needs a good breath force to break through

\section{his block!}

(c) During a clonic stammer, there will be an abnormal expiratory pattern, as air is released during the tremor.

(d) In a tonic block, air is held in the lungs under pressure beneath the level of a closed glottis.

To give re-education exercises is wholly to miss the point and entirely misinterpret these symptoms. All that is required is for these to be pointed out to him, and for him to understand how the first two increase the overt abnormality, and the last two are the direct result of what he is doing with his vocal cords or muscles of articulation. As stammering decreases, so these "symptoms" of abnormal breathing decrease or disappear. If breathing exercises are claimed to be effective, then it is important to realise that this is either due to the effects of suggestion, where the stammerer's conviction of their efficiency overcomes his fear of stammering (which is highly unlikely) or where, in concentrating on his breathing, they serve as a distraction device. The block can obviously be eliminated if the stammerer is really thinking so hard about his breathing, and how to control it, that he is too busy to do the other things which normally interfere with his speech. This interference will be discussed in a later section.

Basically, our approach is two-fold: the first and most important is to change attitude towards the stammer; the second is to bring about change and modifications in the abnormal speech behaviour. In practice it is found that work on changing one always affects and re-inforces the other. Without a profound change in attitude towards stammering, little can be expected in the way of progress. This is why we feel that therapies directed towards achieving speech fluency without adequate work on attitude is bound to have limited or transient effect. It is easy enough to achieve fluency by various means in the clinical situation through general relaxation, suggestion and distraction techniques. Emphasis tends to be placed on fluency as a criterion of progress. The stammerer is greatly encouraged by this fluency, but it is based on the flimsiest of foundations, and he is correspondingly depressed and discouraged, when under stress conditions he blocks as severely as before. We 
could have learned a great deal more about stammering if it had really been understood why methods had apparently succeeded which had no business to succeed at all! So often the prestige of the therapist, distraction, and suggestion generally, were responsible in cases where the techniques, methods or exercises used have been given the credit. This would not matter if we could rely on such therapies to be successful with most stammerers and also for the effects to be lasting. One can well understand why Demosthenes' pebbles could have been successful! We may imagine the distraction afforded by trying to speak with a mouthful of pebbles, and the concentration required not to swallow them!

In our present day, one can appreciate the strong suggestion involved when diagnosis and treatment are carried out under extremely clinical conditions, with remedial exercises, hypnotherapy, sedation, investigations into respiratory, cardiac and nervous function, etc. The stammerer becomes convinced that his stammering is a manifestation of a physical abnormality, if he did not already believe this to be so. The same thing seems to occur after extensive psychotherapy, particularly psychoanalysis, where the patient becomes convinced that his stammering is symptomatic of some deep emotional conflict. The stammerer echoes "I am convinced that if I could find the cause, my stammering would be cured." Many causes are found for him, some he will accept, others he will reject. This often prevents his looking objectively at his stammering behaviour as something he is doing both to interfere with speech and to increase the abnormality of his behaviour. As Dean Williams says, "As long as one functions as though an 'It' makes things happen, he is not motivated to observe cause and effect relationships in his behaviour, for ' $\mathrm{It}$ ' is both cause and effect". Further, "He talks and acts as though he believes either that there exists a little man inside him eager to grab certain words, or that certain words are possessed of physical properties such that they get stuck in his throat".

We are basically in agreement with the semantogenic approach to stammering (Johnson 1957). We feel, however, that a full consideration of this theory is not within the scope of this paper. We profess to an eclectic philosophy, drawing our information from fields related and unrelated to speech pathology.

\section{The Psycho-physiology of Stammering.}

When an individual stammers we are confronted by several different categories of behaviour. When he anticipates difficulty we may observe avoidance of a specific word, rearrangement of words or a total avoidance of speech. Some will interject a sound, word or phrase whilst others will resort to such activities as taking a breath or swallowing to delay blocking. This behaviour is almost always initiated consciously and the stammerer is usually well aware of this fact. Some will complain, however, that it happens so quickly that it is apparently automatic.

The actual blocking or repetition appears to represent a loss of conscious volitional control. We would suggest that this is mainly due to a lack of feedback of information, made worse by the stammerer's emotional state. We would not consider that his general tension, however severe, is the cause of blocking. It is by exerting specific laryngeal tension that he directly interferes in the process of phonation, either disrupting the production of voice or preventing it altogether. The laryngeal activity clearly described by Kenyon (1943) has been largely ignored by most workers. Not only can one observe glottal closure or clonus on vowels and diphthongs, but an identical action occuring on both voiced and voiceless consonants. We are all familiar with the phenomenon of the distorted voiced plosive which a stammerer may produce as an ejective: e.g. p'read and p'utter. Another common feature is the emission of a constricted flow of air which will permit the utterance of a voiceless sound but does not involve the vibration necessary for a voiced consonant or following vowel. One can imitate these phenomena by holding one's breath as lightly as possible and then "trying" to phonate. Further information may be gained by employing a throat microphone with a suitable amplifier and comparing the sounds resulting from both geuine and assumed stammering. Our observations would tend to confirm; the conclusions reached by Dean Williams (1955) in his electromyographic studies, namely that "there was no significant difference between action potentials produced by stammerers and those 
by normal speakers simulating stammering.

The stammerer undergoes all the normal physical manifestations of a state of fear, which he identifies as "feelings of stammering". These are, however, easily recognised in most Speech Therapy Students if they are required to simulate stammering or other speech disorders in everyday, communicative situations. The stammerer usually interprets these features as predictable constituents of stammering behaviour, losing their true identity in the total subjective pattern.

The interference in phonation is sustained until the stammerer is compelled to give up through lack of oxygen or until he is satisfied that sufficient effort has been expended. (c.f. Van Riper, 1956). Some stammerers appear to depend upon a specific time-lag before releasing the word, whilst others wait until they have performed some efficacious movement or ritual. Although different in form, there are basic similarities between blocking and repetitive stammering; the one involving a deliberate tonic closure whilst the other represents the employment of insufficient effort or will to overcome a corresponding resistance of the mechanism, giving rise to oscillation or "hunting" (Wolf, 1959).

When the stammerer is in a state of panic he perceives his own behaviour only through vague tactile and kinaesthetic impressions. Visual feedback is usually not operative and auditory feedback has either broken down, or is wrongly interpreted. The feeling of relief and even success on utterance of the word serve as adequate reinforcement for the conviction that the word will not "come out" without invoking this blind intervention. His lack of awareness of what has actually occurred is manifest in his firm belief of the "difficulty" of certain sounds and words and his incredulous rejection of any suggestion that he is interfering.

This general pattern of behaviour is discernable in individuals widely divergent in temperament, intellectual ability, social background and experience. There is an interesting parallel in some of the findings quoted by Sargant (1957) from his studies of indoctrination, which may give a clue to some of the factors in the development and perpetuation of stammering.
"The normal extravert, for instance, seems to be 'got at' more easily, and his new patterns maintained, by quite crude and nonspecific group excitatory methods, provided that they result in a strong, continued and often repeated emotional arousal . The obsessional person or the intravert may be more unresponsive to such an approach". Sargant offers ample evidence of the ways in which emotion, confusion, hunger and general debilitation facilitate the establish. ment of new attitudes and corresponding changes in behaviour.

The study of Cybernetics promises to be a further aid in our understanding of the problem. Many attempts have been made to interfere with the stammerer's auditory feedback, delaying it or eliminating it with the aid of "white" sound. Some of the inferences drawn from such intervention are rivalled only by those of the stammerer himself, without the advantage of expensive or ingenious equipment.

The laryngeal behaviour in stammering is of paramount importance in that it involves little or no conscious perception of feedback. There appears to exist a dichotomy between motor skills learnt with the aid of visual and kinaesthetic feedback and those dependent upon auditory feedback. In view of the remarkable rapidity with which articulatory skills are acquired and applied, and the comparative ease with which they are performed by the vast majority of human beings, are there not grounds for the assumption that learning to articulate is purely a matter of organising the maturing 'endogenous' behaviour patterns to meet the requirements of one's linguistic environment? (Gesell 1942, Ballard and Bond 1960). Even some stammerers with a high degree of insight find it hard to believe that effort on their part will not facilitate speech but inhibit it, that their simple movements of lips, tongue or larynx which resemble speech sounds are in fact only caricatures of the real process.

We would suggest that stammering and some of the dysphonias represent patterns of learned interference dependant upon some element of 'unconscious control'. When a stammerer realises that a situation demands communication, this realisation gives rise to an emotional reaction. It is this reaction which disrupts the hierarchies subserving homeostatic control of behaviour. In stam- 
mering and a few other activities including, some have suggested, arithmetic and sport, initial failure is taken by Society to be a sign that the individual is in fact incapable of improving his performance. When the demand is as frequent as it is in speech, reinforcement of negative attitudes is especially facilitated.

\section{Therapy.}

\section{A. Change of Attitude towards Stammering.}

This is principally carried out through:

(1) Elimination of avoidance at every possible level.

(2) Re-evaluation of audience reactions and social penalties.

(3) Building up his resistance to these social penalties, and to communication stress, both within and without the group situation.

(4) Encouraging observation and discouraging theory.

(5) Increasing his knowledge of the psychology, physiology and phonetics of stammering, and of normal speech.

(6) Development of a sense of humour in studying stammering, audience reactions, and speech situations as a whole.

Undoubtedly, avoidance re-inforces the fear of specific sounds, words and situations, and is probably one of the most important maintaining factors in this functionally autonomous disorder. Whilst avoidance continues, however subtle the avoidance may be, this is a fairly sure sign that the stammerer's attitude has not undergone sufficient change. $\mathrm{He}$ is obviously still embarrassed and anxious to hide the fact that he is a stammerer as far as this is possible. We are all familiar with substitutions of one word for another, but avoidance takes many forms: using the selfservice store for motives other than convenience; using ticket machines rather than approach a booking-office clerk; giving the bus conductor the correct change for your fare, to avoid stating your destination - the list is endless. The stammerer will not be prepared to abandon avoidance in its many manifestations until he is really convinced of the fact that it is largely responsible for maintaining his speech fears, and secondly, that when he begins to eliminate avoidance his speech fears begin to decrease. Only so much can be accomplished by discussion: in the final analysis, he must begin to enter the situations and use the words he is tempted to avoid before he can really discover how pernicious avoidance is. This can be a difficult step, and here the well-integrated group can be of immense value. Students are sent out in pairs to enter various "avoided" situations, to study their own reactions and those of the listener as objectively as possible. This results in a decrease in both the emotional attitude and in the physical concomitants of fear.

One of the most important effects of such an assignment is the very illuminating reevaluation that takes place on audience reactions. We believe that it is the stammerer's assessment of "what the listener thinks" that largely determines his attitude towards his stammer, and we must recognise that imagined social penalties are just as potent in their effect as real penalties. It is just because he is anxious not "to make a fool of himself" and to invoke such penalties, that so much of his energy is devoted towards postponing, disguising and avoiding stammering. The ironic fact is, that far from achieving its purpose, much of this behaviour only adds to the overt abnormality. It is essential, therefore, if we are to discourage such avoidance, and reduce the stammerer's fear and embarrassment, that we encourage him to look more closely and objectively at how people behave when he stammers. With this in mind, he is asked to report not only on his own behaviour and feelings, but to study the behaviour of the listener. Such observations can then be confirmed or denied by his partner. It frequently comes as a revelation that such a high proportion of people show so little reaction, even in the face of marked abnormality. He realises that those who do react are anxious (not unnaturally) to help him, or are as embarrassed as he is, and look away to spare them both! No attempt is made to convince the stammerer that really adverse reactions cannot occur on occasions, but he discovers from his own experience how rare these are, and furthermore begins to appreciate that the listener probably has bigger problems than he has! Through the experience itself, by relating it afterwards, and then through group discussion, he comes to recognise the psychological common denominators underlying much human behaviour.- Practical experience of this kind, even during a single evening, results in a marked decrease in 
much of his previously subjective evaluation, and a not surprising reduction in the frequency and severity of his blocks. He comes to realise that his own emotional feelings may have caused him to make the most exaggerated interpretations of audience reactions frequently on the slimmest possible evidence of previous unpleasant experience.

Bizarre assignments may merely appeal to a sense of bravado, and tend to favour overcompensation, but the right type of assignment, and the good natured penalties of other members of the group, all help to build up the stammerer's emotional "resistance" to social penalties should they occur. As we have already said, however, with increasing experience of every kind of feared and previously avoided situation, he grows steadily more objective and less emotional in his approach to the people to whom he must speak. Humour, which tends to arise quite spontaneously when these outside activities are related, is undoubtedly a tremendously potent factor in producing a change in attitude. We never have to ask a stammerer to tell a funny story about stammering - almost every assignment they carry out seems to be potentially humourous, and they waste no time in making the most of the story! Our Libyan student has his own favourite assignment: first he asks an unsuspecting member of the public what they think about stammerers. Having removed the ground from under their feet with this question, he then proceeds to ask what advice they would give to help a stammerer. The final coup de grace is to pose the following question: "If you had a sister, would you be prepared to give her hand in marriage to a stammerer?". Our favourite response: "Well, of course. After all, he can't help it, can he?"

Direct observations and experience discourage the kind of theorising which tend to handicap the stammerer in his thinking, and which seldom have little to add to the knowledge of either student or therapist. We give a broad joutline of both past and current therapy, so that he may consider them against the background of his own practical experience in the group, and in carrying out assignments. Through this, and the study of stammering behaviour about to be described, we set out to dispel the myth and mystery surrounding stammering, and to encourage as far as we possibly can an enlightened and objective co-operation from the members of the group.

\section{B. Modification of Stammering Behaviour.}

When a member of the group has reached a stage at which he has been able to give up some measure of avoidance, and most of the delaying techniques he has previously employed, he is then encouraged to adopt his new, experimental approach towards modification of his stammering behaviour. Within this group, using communicative situations (e.g. answering questions, interviewing, giving short talks, reading aloud and play reading) he must first endeavour to free himself of both avoidance and interjection. The deterioration in fluency which may result calls for immediate reassurance and support. Senior members of the group prove particularly helpful at this stage.

When stammering occurs, he is encouraged to consider whether or not it was his own interference which prevented the utterance of the word. It is suggested that he rejects the idea of forcing out the word. When he stammers, he normally feels he has little or no control over the situation. With the encouragement and friendly militance of the group, he will still stammer, but his total emotional reaction becomes markedly reduced. He is better able to take note of what is happening, and can begin to deal with the problem. Communicative demand is built up in such a way that when blocking occurs it is often greeted by laughter from everyone including the speaker. His gradual refusal to "conform" to the usual rules, requirements and rituals of the stammering, and his adoption of a more phlegmatic approach, are strongly reminiscent of Sargant's principles of resistance to "brain-washing". It is our belief that the emotional reactions of fear, and of aggression, must be extracted from the everyday speech situations, to allow a more mature approach. This is also achieved by the open discussion of the feelings which surround stammering.

The therapist must alternate between a directive and non-directive role, taking advantage of the friendly rivalry soon developed within the group. It is important to note that the group is rarely aggressive towards any one member. We are, in fact, continually impressed by the tolerance shown towards new members and towards those 
few who verge on the psychoneurotic, exhibiting a degree of acceptance rarely found in many other social groups.

Understanding of the mechanics of stammering is fostered by straightforward descriptions of the Anatomy and Physiology of the systems involved, together with an outline of basic phonetic principles. Practical application of these principles is achieved by use of a mirror and throat microphones (ex. R.A.F. and U.S.A.A.F. originally suggested by an R.A.F. Wireless Fitter attending one of our hospital groups). We were interested to learn of similar work being carried out by Breckwoldt (1962) in which his "laryngoreflectoscope" can be used to show stammerers their laryngeal activity. He observes that Gutzman mentioned the value of autolaryngoscopy in his "Sprachheilkunde".

These "feed-back" techniques help the stammerer to achieve control of his behaviour through increased understanding. He must then begin to employ his new approach to blocking in "field work". The change in behaviour requires constant stabilisation for at least a period of several months. Those who attend irregularly through choice or circumstance tend to take the longest period. We have found, however, that there is rarely a relapse where a major alteration in behaviour and attitude occurs.

\section{Conclusion.}

Therapeutically, class organisation is unique: although we are allowed to limit our regular attendance to 7 or 8 students in a group, should attendance drop below this, then classes can automatically be closed. In this respect, we enjoy no special privileges. Far from being a disadvantage, we realise that this has proved to be an excellent discipline and a stimulating challenge. It has encouraged us, of sheer necessity, to evolve an approach which is designed to integrate a group as rapidly as possible; to create an atmosphere of informality which the students enjoy; and finally, a therapy designed to produce reasonably rapid results. As therapy has been streamlined and developed in this direction, two trends have been noticeable: that few stammerers now cease attendance without reason or explanation, and secondly, a much higher proportion reenrol for the second or third year which is necessary in many cases. Our therapy has evolved from experience and observation of many stammerers, just as the stammerer in the group must finally learn from his own observations and experiences.

Atmosphere in the group is hard to describe. As we have stressed, informality and humour are an essential part. It seems to have been evolved in much the same way as the therapy. These are a few of the factors which have helped to determine it: in the first place, these are students in a study group, not patients in a clinic: they are treated as people with a common problem, not patients with a defect; secondly, they are free to come and discuss particular difficulties before or after class, and individual help is made available whenever necessary; thirdly, every member is given an equal opportunity to participate and succeed (and it is surprising how many students volunteer to participate on their first evening, and find, perhaps for the first time, that they are laughing about their own stammer as well as everyone else's); finally, no attempt is made to create an "easy" atmosphere to facilitate fluency - on the contrary - but the tolerance and humour of the group reduce any emotional trauma to a level which the student can handle, however new or embarrassed he may be.

For the past three years, students have completed a comprehensive questionnaire within a few weeks of joining the group. This helped us to know much more, in the absence of initial interviews, about the stammerer and his attitudes, environment, personality and problems. This year, however, it was decided that some way must be found of measuring progress as objectively as possible so that we can systematically assess the results achieved by this particular approach. Measurement of progress in stammering has always presented special problems. We hope that the form which has been prepared will go a considerable way in overcoming the difficulties of objective evaluation. The form is simple and complete. It will be given to the stammerer four times: at the commencement of the session, and then at the end of the first, second and third terms. It is divided into four parts: the therapist's check list for symptoms of stammering; the stammerer's check list of situations he avoids; the stammerer's own check list of 
stammering behaviour (e.g. looking away from the listener, taking a breath before a difficult word); finally, his check list which indicates his assessment of audience reactions:

(Put a tick against the things people do when you stammer:

Look away

Laugh

Look embarrassed or uncomfortable

Try to help you out with a word

Appear impatient

Behave sympathetically

Treat you as if you are stupid

Appear superior or condescending

Generally react unfavourably

Show little or no reaction.)

A decrease in the number of items ticked will be an indication of both changes in attitudes and of decrease in severity and abnormality of speech behaviour.

\section{SUMMARY.}

The London County Council has for many years held evening classes for adult stammerers. Since 1956, when one of the authors was appointed as therapist, general relaxation as a fundamental form of treatment was abandoned in favour of "non-avoidance" techniques.

Groups consist of stammerers ranging in age from 16 to 55 years. In addition to this wide age range, there are varied racial, social and educational backgrounds. 8 is considered to be the "ideal" number of students for a therapeutic group.

The approach to therapy has been based on the assumption that the stammerer is a "normal" person with a normal speech mechanism, and that stammering can be considered as a functionally autonomous disorder of communication.

Basically the approach to the problem is two-fold: the first and most important is to change the attitude towards the stammer; the second is to bring about change and modifications in the abnormal speech behaviour. Therapies which do not attempt to effect a change in attitude towards stammering, but are directed towards achieving speech fluency, àre bound to have limited or transient effect.

Opsomming.

Die Londonse Distriksraad het vir baie jare aandklasse gereël vir volwasse hakkelaars. Sedert 1956, toe een van die skrywers as 'n terapeut aangestel is, is algemene verslapping as 'n grondbeginsel in terapie afgeskaf tengunste van die "nie-ontwykings" tegniek.

Die groepe bestaan uit hakkelaars, wat wissel in ouderdom van 16 tot 55 jaar. Behalwe vir die groot verskil in ouderdomme, het die groep ook persone ingesluit met 'n verskillende rasse-, sosiale en opvoedkundige agtergrond. Agt studente word beskou as die ideale aantal per groep.

Die benadering tot terapie is gebaseer op die veronderstelling dat die hakkelaar 'n "normale" persoon is met 'n normale spraakmeganisme, en dat hakkel as 'n funksioneeloutonomiese gebrek van kommunikasie, beskou kan word.

Die benadering tot die probleem is basies tweeledig: die eerste en belangrikste is om die houding teenoor die hakkel te verander; die twede is om veranderings en wysigings in die abnormale spraakpatroon teweeg te bring. Behandelings wat nie mik om die houding teenoor die hakkel te verander nie, maar wat gesteld is om vlotheid van spraak te verkry, moet noodwendig beperkte en verbygaande resultate lewer.

\section{REFERENCES}

1. Ballard. C. F. \& Bond, E. K., "Clinical Observations on the Correlation between Variations of Jaw Form and Variations of Oro-facial Behaviour, Including those for Articulation". Speech Pathology \& Therapy, 2, 55-63. (1960).

2. Breckwoldt, G. H., "The Laryngo-reflectoscope." (Unpublished M.s.s.) (1957).

3. Foulkes, S. H. \& Anthony, E. J., "Group Psychotherapy". London: Penguin Books.

4. Gesell, A., "Morphologies of the Mouth and Mouth Behaviour". American Journal of Orthodontics, 27, 397. (1942).

5. Johnson, W. "Perceptual and Evaluational Factors in Stuttering". Handbook of Speech Pathology, Ed. Travis, L. E. New York: Appleton Century Crofts. (1957).

6. Kenyon, E. L., "The Etiology of Stammering: The Psycho-physiological Facts Which Concern the Production of Speech Sounds and Stammering". Journal of Speech Disorders, 8, 337-348. (1943).

7. Sargant, W., "Battle for the Mind - A Physiology of Conversion and Brain Washing". London; Wm. Heinemann. (1957).

8. Van Riper, C., "Speech Correction". New York: Prentice Hall. Inc. (1956).

9. Williams, D. E., "Masseter Muscle Action Potentials in Stuttered and Non-Stuttered Speech". Journal of Speech and Hearing Disorders, 20, 242-261. (1955).

10. Williams, D. E. "A Point of View about 'Stuttering' "Journal of Speech and Hearing Disorders, 22, 390-397. (1957).

11. Wolf, A. A. \& Wolf, E. G., "Feedback Processes in the Theory of Certain Speech Disorders". Speech Pathology and Therapy, 2, 48-55. (1959). 